\title{
Review \\ Advances in Polyhydroxyalkanoate Nanocarriers for Effective Drug Delivery: An Overview and Challenges
}

\author{
Priyanka Prakash ${ }^{1}$, Wing-Hin Lee ${ }^{2}$, Ching-Yee Loo $^{2}$, Hau Seung Jeremy Wong ${ }^{3}$ \\ and Thaigarajan Parumasivam $1, *$ (D) \\ 1 School of Pharmaceutical Sciences, Universiti Sains Malaysia, Minden 11800, Penang, Malaysia; \\ priyankaprakash95@outlook.com \\ 2 Faculty of Pharmacy and Health Sciences, Royal College of Medicine Perak, \\ Universiti Kuala Lumpur (RCMP UniKL), Ipoh 30450, Perak, Malaysia; whlee@unikl.edu.my (W.-H.L.); \\ cyloo@unikl.edu.my (C.-Y.L.) \\ 3 School of Biological Sciences, Universiti Sains Malaysia, Minden 11800, Penang, Malaysia; \\ jeremywong@student.usm.my \\ * Correspondence: thaigarp@usm.my; Tel.: +60-4-6577888
}

check for updates

Citation: Prakash, P.; Lee, W.-H.; Loo, C.-Y.; Wong, H.S.J.; Parumasivam, T. Advances in Polyhydroxyalkanoate Nanocarriers for Effective Drug Delivery: An Overview and Challenges. Nanomaterials 2022, 12, 175. https://doi.org/10.3390/ nano12010175

Academic Editor: Anna Piperno

Received: 29 October 2021

Accepted: 7 December 2021

Published: 5 January 2022

Publisher's Note: MDPI stays neutral with regard to jurisdictional claims in published maps and institutional affiliations.

Copyright: (c) 2022 by the authors. Licensee MDPI, Basel, Switzerland. This article is an open access article distributed under the terms and conditions of the Creative Commons Attribution (CC BY) license (https:// creativecommons.org/licenses/by/ $4.0 /)$.

\begin{abstract}
Polyhydroxyalkanoates (PHAs) are natural polymers produced under specific conditions by certain organisms, primarily bacteria, as a source of energy. These up-and-coming bioplastics are an undeniable asset in enhancing the effectiveness of drug delivery systems, which demand characteristics like non-immunogenicity, a sustained and controlled drug release, targeted delivery, as well as a high drug loading capacity. Given their biocompatibility, biodegradability, modifiability, and compatibility with hydrophobic drugs, PHAs often provide a superior alternative to free drug therapy or treatments using other polymeric nanocarriers. The many formulation methods of existing PHA nanocarriers, such as emulsion solvent evaporation, nanoprecipitation, dialysis, and in situ polymerization, are explained in this review. Due to their flexibility that allows for a vessel tailormade to its intended application, PHA nanocarriers have found their place in diverse therapy options like anticancer and anti-infective treatments, which are among the applications of PHA nanocarriers discussed in this article. Despite their many positive attributes, the advancement of PHA nanocarriers to clinical trials of drug delivery applications has been stunted due to the polymers' natural hydrophobicity, controversial production materials, and high production costs, among others. These challenges are explored in this review, alongside their existing solutions and alternatives.
\end{abstract}

Keywords: drug delivery; polyhydroxyalkanoates; nanocarrier; nanotechnology; challenges

\section{Introduction}

In today's modern society, the leaps and bounds taken by medical advancements are no stranger to humankind. That being said, drug delivery systems (DDSs), otherwise defined as pharmaceutical apparatus or formulations that aid in the sustained, targeted release of a therapeutic agent [1], have also become increasingly efficient, with the utilization of modern technology and techniques to enhance the transport and release of drugs once administered to patients. However, despite best efforts, side effects can crop up because of the unsuitability of the drug and/or its administration route, as well as the patient's immune response. To avoid undesirable side effects and enhance healing, it is essential that the drug concentration be sustained at its optimal therapeutic range, which would involve a delicate blend of an appropriate number of doses, a suitable administration route, a controlled rate of drug release, as well as the right type of DDS [2]. Given these stringent requirements to ensure effective treatment, it is crucial that promising options for DDSs be explored thoroughly, and one such candidate is the nanocarrier.

Nanocarriers are a relatively new delivery system characterized by therapeutic particles with a size of less than $500 \mathrm{~nm}$ [3-5]. Their high surface-area-to-volume ratio gives rise 
to many desirable characteristics such as enhanced biodistribution, increased stability, and improved bioactivity and pharmacokinetics [6]. Their nanosize is also particularly useful as it allows the nanocarriers more freedom to traverse the human body compared to DDSs of larger size [7]. Nanocarriers can also remain in the circulatory system for an extended period, which not only eases drug release according to their doses, but also decreases unwanted side effects [8]. In order to achieve targeted delivery while also bypassing the biological barriers in the human body that might denature or degrade the drug, nanocarriers have to be designed appropriately using a material with suitable properties [9], and this is where polyhydroxyalkanoates come into the picture.

Polyhydroxyalkanoates (PHAs) are biopolymers that are naturally produced by certain types of bacteria and other organisms as an energy source during periods of unstable growth. When certain nutrients become limited and carbon is excessive, PHA granules are synthesized by bacterial cells for long-term survival. PHA-producing microorganisms include Cupriavidus necator, Chromatium vinosum, and Pseudomonas aeruginosa [10]. PHA consists mostly of short-chain-length hydroxyalkanoic acids (scl-PHAs) with monomers of three to five carbon atoms and medium-chain-length hydroxyalkanoic acids (mcl-PHAs) with monomers of six to fourteen carbon atoms. A less common class of PHA is long-chainlength hydroxyalkanoic acids (lcl-PHAs), which have monomers of more than fourteen carbon atoms [11]. PHAs as shown in Figure 1 are popular in the field of nanomedicine, given their high loading capacity, biocompatibility, lack of toxicity, and biodegradability [12]. PHAs triumph over other bioplastics in the medical field because their monomers 3-hydroxybutyric acid (3HB) and 4-hydroxybutyric acid (4HB) are recognized by the human body as degradation products, conveniently resulting in their swift, natural removal from the body [13]. Additionally, PHA-based DDSs have proven to be highly effective because they can achieve a targeted drug delivery with the aid of targeting ligands and can also provide a controlled release of the incorporated drugs [14]. Hence, it is no surprise that PHAs have been utilized in DDSs for cancer therapy and other diverse applications [15].

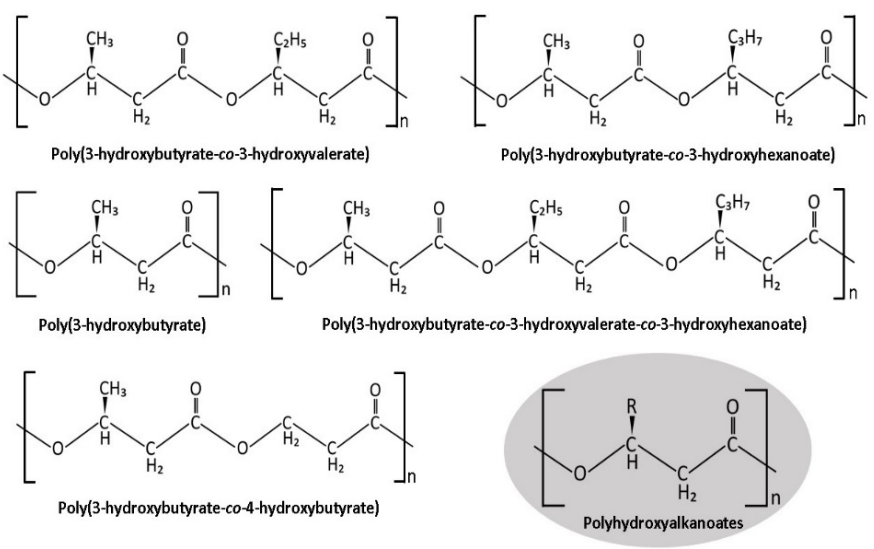

Figure 1. Chemical structures of $\mathrm{P}(3 \mathrm{HB}-c o-3 \mathrm{HV}), \mathrm{P}(3 \mathrm{HB}-c o-3 \mathrm{HHx}), \mathrm{P}(3 \mathrm{HB}), \mathrm{P}(3 \mathrm{HB}-c o-3 \mathrm{HV}-c o-3 \mathrm{HHx})$, $\mathrm{P}(3 \mathrm{HB}-\mathrm{co}-4 \mathrm{HB})$, and PHA.

Despite having many redeeming qualities, certain characteristics of PHAs may discourage their use in the medical field. Some of these include a high hydrophobicity, low thermal stability, and a slow degradation rate [16]. However, their most notable drawback lies in their high production costs, which in turn hinder the commercialization of PHAs. This is also the reason PHAs tend to be overlooked for usage in medical applications despite their ideal properties. Their high price is the consequence of a need for a large amount of substrates with high purity, as well as their labor-intensive production and downstream processing [17]. To amend this, researchers have taken to exploring more sustainable alternatives such as using waste materials as carbon sources, and replacing chemical extraction methods with biological ones. In time, PHAs will undoubtedly claim their place at the 
forefront of superior biomaterials, which will encourage their advancement into clinical trials in the development of nanocarriers as therapeutic agents.

This review explores current formulation strategies and applications of PHA nanocarriers in DDSs alongside their pharmacokinetics, pharmacodynamics, and other key findings. The article also looks into the challenges of utilizing PHAs in nanomedicine, as well as existing solutions to them.

\section{Formulation of PHA Nanocarriers}

In the past decade, PHA-based nanoparticles as drug carriers have garnered significant attention for treating various diseases, owing to their potential to improve existing drug delivery systems via the design of novel dosage forms. Such formulations could have a better treatment outcome than conventional therapy due to their promising physicochemical properties as mentioned earlier [18], including (i) the ability to overcome the solubility of hydrophobic drugs, (ii) being readily manipulated for active targeting, (iii) the stabilization of chemotherapeutic agents, (iv) full biocompatibility and non-immunogenicity, and (v) superior pharmacokinetics and pharmacodynamics compared to free drug therapy [19-23]. However, US Food Drug Administration (FDA)-approved PHA-based nanomedicines for treatment are unavailable. PHA and nanotechnology-based therapies are still in the experimental stages, and clinical trials are significantly lagging.

PHA-based nanoparticles have been explored for the encapsulation of a wide range of therapeutic agents, including anticancer agents, antibiotics, hormones, and vaccines [24,25]. Different formulation strategies have been explored to produce PHA nanoparticles, including emulsion solvent evaporation techniques (i.e., oil-in-water $(\mathrm{O} / \mathrm{W})$ single emulsion, and water-in-oil-in-water (W/O/W) double emulsion), nanoprecipitation, dialysis, and in situ polymerization techniques [26-29] as summarized in Table 1 . The selection of the formulation approach mainly depends on the intended particle size, morphology, and solubility of the target drug and the polymer. The emulsion solvent evaporation method has been utilized the most to produce PHA-based nanoparticles because this technique eases control of the processing parameters and allows encapsulation of both hydrophobic and hydrophilic drugs [30]. Generally, the drug is either dissolved or emulsified in the oil phase, then further emulsified in the continuous aqueous phase, as shown in Figure 2. This is followed by solvent evaporation to allow the hardening of the particles. The particles are then washed with distilled water, collected via centrifugation, and freeze-dried for long-term storage [31].

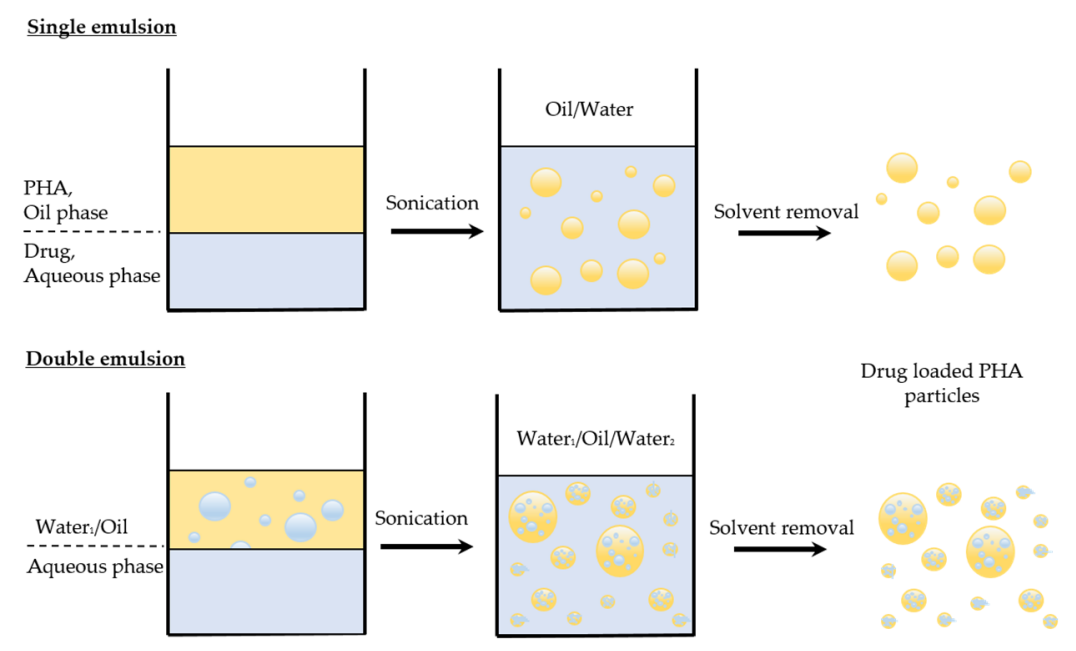

Figure 2. The emulsion solvent evaporation method to produce PHA nanoparticles. The drug is either dissolved in the oil phase with the PHA (oil/water, single emulsion) or emulsified in the oil phase (water 1 / oil/water 2 , double emulsion) and then further emulsified in the continuous water phase. This is followed by solvent evaporation and washing with distilled water. 
For instance, in a recent study, $\mathrm{Hu}$ and co-workers produced poly(3-hydroxybutyrateco-3-hydroxyvalerate-co-3-hydroxyhexanoate) (PHBVHHx) nanoparticles loaded with immunosuppressant drug azathioprine for the potential treatment of systemic lupus erythematosus using the emulsion solvent technique. The particles not only had acceptable toxicity and slow clearance from kidneys, but they also exhibited a higher therapeutic effect compared to polylactic acid (PLA) nanoparticles when tested in a murine systemic lupus erythematosus model [32]. Similarly, Xiong et al. reported that poly(3-hydroxybutyrate) (PHB) and poly(3-hydroxybutyrate-co-12 mol\% 3-hydroxyhexanoate) (PHBHHx) nanoparticles with a size range of $160-250 \mathrm{~nm}$ loaded with rhodamine B isothiocyanate (a lipidsoluble dye) deeply penetrated macrophages and prolonged drug release to about 20 days compared to its PLA counterpart which took about 15 days. This proves that PHA-based nano-systems can provide a slower drug release with an enhanced therapeutic index compared to PLA nanoparticles that have been well-studied as a drug control release system.

The surface of PHA nanoparticles can also be functionalized to enhance the localization of the particles in the vicinity of the cells. For example, curcumin-loaded and conjugated with targeting ligand concanavalin A in poly(3-hydroxybutyrate-co-3-hydroxyhexanoate) (PHBHHx) nanoparticles (average size of $228 \pm 5 \mathrm{~nm}$ ) showed enhanced cellular uptake and apoptotic activity in breast cancer cells compared to the non-functionalized nanoparticles [33]. A similar higher in vitro cellular uptake was reported with etoposide (an antineoplastic agent)-loaded poly(3-hydroxybutyrate-co-3-hydroxyhexanoate) (PHBHHx) nanoparticles functionalized with folic acid in HeLa cells [34]. As anticipated, $\mathrm{P}(3 \mathrm{HV}-\mathrm{co}-4 \mathrm{HB})-b-$ $\mathrm{mPEG}$, an amphiphilic poly(3-hydroxyvalerate-co-4-hydroxybutyrate) and polyethylene glycol nanoparticle, enhanced the apoptotic activity of the encapsulated cisplatin compared to the free drug-treated group using a DU145 prostate cancer cell line [35]. Thus, these findings merit that PHA nanoparticles, like other polymeric nanoparticles, are suitable for targeted drug delivery systems when conjugated with targeting moieties.

On the other hand, a common drawback of PHB nano-delivery systems, especially those using scl-PHB, is the rapid release of the encapsulated drugs. However, this problem can be mitigated by conjugating the drug molecule to the PHB polymer to slow the drug release [36]. Additionally, the rapid release of scl-PHB can be altered by converting it into PHB glyoxylate via ozonolysis for a slow release of drugs possessing primary amine groups [37]. Hence, the development of PHA-drug conjugates opens a new window for novel slow-release drug delivery therapies.

Similar to other colloidal systems, PHA nanoparticles also suffer the disadvantage of poor drug loading [38]. For instance, a drug loading of less than $30 \%$ has been reported in various studies $[30,35,39-43]$. As a solution, the strategies reported for other polymers such as PLGA can be used as a guideline to increase the drug loading of PHA-based nanoparticles. An extensive review of strategies to increase the drug loading of polymeric particles can be found at $[30,44]$. 
Table 1. Key findings of various polyhydroxyalkanoate (PHA) nanoparticle formulations.

\begin{tabular}{|c|c|c|c|c|c|c|}
\hline Polymer & Drug & Size (nm) & Drug Loading (\%) & Formulation Method & Key Findings & Ref. \\
\hline Poly(3-R-hydroxyalkanoate) & $\begin{array}{l}\text { Calcein and Nile } \\
\text { red }\end{array}$ & 155 & - & Nanoprecipitation & $\begin{array}{l}\text { Unsaturated PHA is suitable to } \\
\text { make controlled } \\
\text { release nanomedicine. }\end{array}$ & [45] \\
\hline $\begin{array}{c}\text { Poly(3-hydroxybutyrate-co-3-hydroxyvalerate-co- } \\
\text { 3-hydroxyhexanoate) } \\
\text { (PHBVHHx) }\end{array}$ & Azathioprine & 95.7 & - & Modified emulsion & $\begin{array}{l}\text { The particles have acceptable } \\
\text { toxicity and slow clearance from } \\
\text { kidneys, with a higher therapeutic } \\
\text { effect than polylactic acid (PLA) } \\
\text { nanoparticles when tested in a } \\
\text { murine systemic lupus } \\
\text { erythematosus model. }\end{array}$ & [32] \\
\hline $\begin{array}{l}\text { Poly(3-hydroxybutyrate-co-3-hydroxyhexanoate) } \\
\text { (PHBHHx) }\end{array}$ & Curcumin & $273 \pm 84$ & $15-30$ & Solvent evaporation & $\begin{array}{l}\text { Lyophilization is suitable for } \\
\text { preserving the nanoparticles at } 4{ }^{\circ} \mathrm{C} \text {. } \\
\text { The particles had high apoptotic } \\
\text { activity and localization into } \\
\text { MDA-MB-231 cells. }\end{array}$ & [33] \\
\hline $\begin{array}{l}\text { Poly(3-hydroxybutyrate-co-3-hydroxyhexanoate) } \\
\text { (PHBHHX) }\end{array}$ & Etoposide & $180-1500$ & $2.92-8.77$ & $\begin{array}{l}\text { Modified solvent } \\
\text { evaporation }\end{array}$ & $\begin{array}{l}\text { Folic acid-conjugated nanoparticles } \\
\text { have higher selectivity to cancer } \\
\text { cells than fibroblast cells. }\end{array}$ & [34] \\
\hline Poly(3-hydroxyvalerate-co-4-hydroxybutyrate) & Cisplatin & $155 \pm 5$ & $9.58 \pm 1$ & $\begin{array}{l}\text { Emulsification-solvent } \\
\text { evaporation }\end{array}$ & $\begin{array}{l}\text { Cisplatin-loaded PHA nanoparticles } \\
\text { accumulated in tumour cells and } \\
\text { showed significant tumour } \\
\text { deterioration compared to free } \\
\text { drug treatment. }\end{array}$ & [35] \\
\hline $\begin{array}{l}\text { Poly(3-hydroxybutyrate-co-3-hydroxyvalerate) } \\
\text { (PHBV) }\end{array}$ & Nile red & $166-426$ & - & Oil-in-water emulsion & $\begin{array}{l}\text { The nanoparticles penetrated the } \\
\text { skin of the BALB/c mouse model } \\
\text { without adverse effects. }\end{array}$ & [46] \\
\hline $\begin{array}{c}\text { Poly (3-hydroxybutyrate-co- } 12 \mathrm{~mol} \% \\
\text { 3-hydroxyhexanoate) (PHBHHx) and } \\
\text { Poly (3-hydroxybutyrate-co-5 mol\% } \\
\text { 3-hydroxyhexanoate) (PHBV) }\end{array}$ & TGX-221 & $195-220$ & $8.5-8.8$ & $\begin{array}{l}\text { Modified } \\
\text { emulsification/solvent } \\
\text { diffusion }\end{array}$ & $\begin{array}{l}\text { The encapsulation of TGX-221 in } \\
\text { PHA nanoparticles could mitigate } \\
\text { the poor bioavailability and limited } \\
\text { in vivo half-life of the TGX-221. }\end{array}$ & [39] \\
\hline
\end{tabular}


Table 1. Cont.

\begin{tabular}{|c|c|c|c|c|c|c|}
\hline Polymer & Drug & Size (nm) & Drug Loading (\%) & Formulation Method & Key Findings & Ref. \\
\hline $\begin{array}{l}\text { Poly-3-hydroxybutyrate-co-5 mol\% } \\
\text { 3-hydroxyvalerate (PHBV-S), } \\
\text { poly-3-hydroxybutyrate-co-11 mol\% } \\
\text { 3-hydroxyvalerate (PHBV-11) and } \\
\text { poly-3-hydroxybutyrate-co-15 mol\% } \\
\text { 3-hydroxyvalerate (PHBV-15) }\end{array}$ & Ellipticine & $184-283$ & - & $\begin{array}{l}\text { Modified } \\
\text { emulsification-solvent } \\
\text { evaporation }\end{array}$ & $\begin{array}{l}\text { The particles showed no inhibition } \\
\text { of the A549 cancer cell line at } \\
\text { various tested concentrations (i.e., } \\
250.0,62.5 \text {, and } 15.6 \mu \mathrm{g} / \mathrm{mL} \text { ). }\end{array}$ & [47] \\
\hline $\begin{array}{l}\text { Poly(3-hydroxybutyrate-co-3-hydroxyhexanoate) } \\
\text { (PHBHHx) }\end{array}$ & Rapamycin & 200 & $8.47-8.52$ & $\begin{array}{l}\text { Emulsification-solvent } \\
\text { evaporation }\end{array}$ & $\begin{array}{l}\text { The particles showed an efficient } \\
\text { entrapment of } 91.9 \% \text { and a } \\
\text { sustained release of rapamycin for } \\
\text { almost } 10 \text { days. Cellular uptake of } \\
\text { PEG200 end-capped nanoparticles } \\
\text { was significantly higher than that of } \\
\text { non-PEG nanoparticles in a human } \\
\text { prostate cancer cell line and a } \\
\text { murine macrophage cell line. }\end{array}$ & {$[40]$} \\
\hline $\begin{array}{c}\text { Polyhydroxybutyrate, } \\
\text { poly(hydroxybutyrate-co-hydroxyvalerate) } \\
\text { P(HB-HV) with } 12 \text { and } 50 \% \mathrm{HV}\end{array}$ & $\begin{array}{c}5,10,15,20- \\
\text { Tetrakis(4- } \\
\text { hydroxy-phenyl)- } \\
21 H, \\
\text { 23H-porphine }\end{array}$ & $169.0-211.2$ & $0.91-46.64$ & Emulsification-diffusion & $\begin{array}{l}\text { The particles showed a } \\
\text { concentration and time-dependent } \\
\text { photocytotoxicity in a human colon } \\
\text { adenocarcinoma cell line. }\end{array}$ & {$[48]$} \\
\hline $\begin{array}{l}\text { Poly(3-hydroxyoctanoate-co-3-hydroxyhexanoate) } \\
\qquad \text { (PHOHHx) }\end{array}$ & - & $44-90$ & - & Dialysis & $\begin{array}{l}\text { A series of diblock copolymers of } \\
\text { PHOHHx with poly(ethylene } \\
\text { glycol) (PEG) were synthesized } \\
\text { using "click" chemistry and } \\
\text { assembled into micelles for } \\
\text { drug delivery. }\end{array}$ & [29] \\
\hline $\begin{array}{c}\text { Poly(3-hydroxybutyrate-co-3-hydroxyvalerate) } \\
\text { P(3HB-co-3HV) or } \\
\text { poly(3-hydroxybutyrate-co-4-hydroxybutyrate) } \\
\text { P(3HB-co-4HB) }\end{array}$ & Thymoquinone & $112-162$ & - & $\begin{array}{l}\text { Modified } \\
\text { emulsification-solvent } \\
\text { evaporation }\end{array}$ & $\begin{array}{l}\text { The chemical combination of PHA } \\
\text { copolymers and mPEG-based } \\
\text { nanoparticles was nontoxic and } \\
\text { biocompatible to prenatal rat } \\
\text { neuronal hippocampal and } \\
\text { NIH/3T3 fibroblast cells in vitro. }\end{array}$ & [49] \\
\hline
\end{tabular}


Table 1. Cont.

PEG-conjugated PHB nanoparticles

showed a sustained release of

NuBCP-9 for up to 26 days and

efficient cellular uptake in a

Double emulsion solvent

evaporation

time-dependent manner in MCF-7

cells. A 90\% tumour regression was

seen when particles were administered intraperitoneally

twice a week for three weeks in an Ehrlich syngeneic mouse model.

PHB functionalized with

tumour-specific ligand

nanoparticles showed a specific affinity to MDA-MB-231 breast cancer cells.

solvent evaporation

The recombinant human a1-acid glycoprotein or recombinant human

epidermal growth factor

functionalized nanoparticles were taken up by macrophages and hepatocellular carcinoma cells.

Oil-in-water emulsion

An increase of the polymer

Miniemulsification and emulsion/solvent concentration led to a larger particle evaporation size due to a change in viscosity.

Co-encapsulation of dual anticancer drugs was achieved. A sustained and faster drug release was observed for doxorubicin and sorafenib, respectively.

The particles interacted with 
Table 1. Cont.

\begin{tabular}{|c|c|c|c|c|c|c|}
\hline Polymer & Drug & Size (nm) & Drug Loading (\%) & Formulation Method & Key Findings & Ref. \\
\hline Polyhydroxyalkanoate (PHA) & - & $145-159$ & - & Oil-in-water emulsion & $\begin{array}{l}\text { The PHA nanoparticles showed } \\
\text { antibacterial activity against } \\
\text { S. aureus, S. pneumoniae, E. coli, } \\
\text { K. pneumoniae, and P. aeruginosa. }\end{array}$ & [55] \\
\hline $\begin{array}{l}\text { Poly(3-hydroxybutyrate-co-3-hydroxyoctanoate) } \\
\qquad(\mathrm{P}(\mathrm{HB}-\mathrm{HO}))\end{array}$ & Doxorubicin & 240 & 29.6 & $\begin{array}{l}\text { Water-in-oil-in-water } \\
\text { solvent } \\
\text { extraction/evaporation }\end{array}$ & $\begin{array}{l}\text { Doxorubicin-loaded } \\
\text { folate-mediated nanoparticles were } \\
\text { readily internalized by HeLa cells } \\
\text { in vitro. }\end{array}$ & [42] \\
\hline Polyhydroxybutyrates (PHB) & $\begin{array}{l}\text { Concanavalin-A } \\
\text { and etoposide }\end{array}$ & $239.43 \pm 5.25$ & - & Multi-emulsion & $\begin{array}{l}\text { Iron oxide particles were } \\
\text { successfully coated with PHB. The } \\
\text { cytotoxicity of these magnetic PHB } \\
\text { particles were reported against } \\
\text { cancer and non-cancer cells. }\end{array}$ & [56] \\
\hline Poly(hydroxybutyrate-co-hydroxyvalerate) (PHBV) & Fingolimod & 250 & $0-22.5$ & $\begin{array}{l}\text { Single and double } \\
\text { evaporation }\end{array}$ & $\begin{array}{l}\text { The optimal preparation of PHBV } \\
\text { nanoparticles required a polymer } \\
\text { concentration of } 1.32 \% \text {, a PVA } \\
\text { concentration of } 0.42 \% \text {, and } 5 \mathrm{mg} \text { of } \\
\text { the drug. }\end{array}$ & [43] \\
\hline
\end{tabular}

Note: '-' indicates the value was not reported. 


\section{Applications of PHA Nanocarriers}

\subsection{Treatment of Cancer}

PHA nanoparticles have been suggested as an alternative to conventional polymeric nanoparticles, namely poly(D,L-lactide-co-glycolic) acid (PLGA)-based nanocarriers, for the delivery of hydrophobic anticancer agents for therapeutic purposes [41]. Di Mascolo et al. demonstrated that the cytotoxic potential of docetaxel (DCT)-loaded poly(3hydroxybutyrate) $\mathrm{P}(3 \mathrm{HB})$ nanoparticles (DCT-P3HB-NPs) against U-87 MG cells was comparable to DCT-loaded PLGA-NPs [57]. However, owing to the hydrophobic characteristic of $\mathrm{P}(3 \mathrm{HB})$ compared to PLGA, it allowed higher drug loading (by twofold) and a slower drug release [57]. Additionally, the degradation product of $\mathrm{P}(3 \mathrm{HB})$ is 3-hydroxybutyric acid which is non-toxic in blood plasma compared to the acidic degradation products of PLGA that could lead to inflammation.

One of the drawbacks of PHAs which hampers their application as a carrier is their limited solubility due to their hydrophobicity. An amphiphilic PHB copolymer incorporating the hydrophilic polyethylene glycol (PEG) was synthesized via transesterification reactions to overcome $\mathrm{PHB}^{\prime}$ 's hydrophobicity [58]. This modification also prevented the opsonization and phagocytic clearance of PHB as well as enhanced the cellular uptake [59]. Subsequently, the authors evaluated the effectiveness of PHB-co-PEG copolymer nanoparticles loaded with an antisense oligonucleotide (ASN) against breast (MDA-MB-231) and lung (A549) cancer cell lines [58]. The viabilities of A549 and MDA-MB-231 cells exposed to $200 \mathrm{mg} / \mathrm{mL}$ of ASN-loaded PHB copolymeric nanoparticles were $49.89 \%$ and $35.34 \%$, respectively. The authors demonstrated that the use of PHB copolymeric nanoparticles protected ASN from enzymatic degradation as well as enhanced its cellular internalization [58]. When conferring hydrophilic properties onto PHA, the molecular weight of PEG is also important to control the loading efficacy and drug release rate [60]. PEG can also form a stable complex with enzymes, which can then be immobilized onto PHB nanoparticles for improved anti-proliferative activity against cancer cells. In a study by Pandian et al., L-glutaminase/PEGylated-PHB nanoparticles enhanced the inhibition of HeLa cell proliferation in vitro via glutamine deprivation [61]. A significant increase in DNA damage, ROS production, and caspase-3 levels was in line with the successful delivery of L-glutaminase using PEGylated-PHB nanoparticles [61].

Besides that, the functionalization of O-carboxymethyl chitosan (CMCh) onto PHB nanoparticles during synthesis was another approach to overcome its hydrophobicity and solubility issues [62]. The etoposide-loaded CMCh-PHB nanoparticles (ETP-CMCh-PHB NPs) stabilized with polyvinyl alcohol were negatively charged and displayed a sustained release behaviour. When treated with $100 \mu \mathrm{g} / \mathrm{mL}$ of ETP-CMCh-PHB NPs and blank CMCh/PHB, the viability of MCF-7 cells was $61.13 \%$ and $101.8 \%$, respectively [62].

Masood et al. studied the effects of different hydroxyvalerate (3HV) units within a PHB copolymer to determine its suitability as a nanocarrier for anticancer agents [47]. Irrespective of the $3 \mathrm{HV}$ monomer content, the ellipticine-loaded PHB-co-3HV nanoparticles demonstrated no statistical differences in their cytotoxic effect against A549 cancer cells. Nonetheless, these nanoparticles incited a higher cell inhibition of almost twofold compared to free ellipticine [47]. As the degradation rate of PHB-co-3HV nanoparticles is slow, the concentration of the released drug from the polymeric nanoparticle is expected to be low. As demonstrated by Vilos et al., less than 1\% of paclitaxel (PTX) was released over a 5-day period in physiological buffered media ( $\mathrm{pH}$ 7.4), which suggests that a highly specific targeted application be considered in the future for this nanoparticle [63]. This finding is in agreement with previous work whereby a sustained drug release profile that lasted for more than 20 days was observed for PHB and poly(3-hydroxybutyrate-co-3hydroxyhexanoate) (PHB-co-HHx) nanoparticles [64]. To assess the clinical relevance of fabricated PTX-loaded PHB-co-3HV NPs, six primary cell cultures obtained from patients undergoing treatment for stage IIIc papillary serous ovarian cancer were treated with $5 \mu \mathrm{M}$ of PTX-loaded PHB-co-3HV NPs and PTX alone for $48 \mathrm{~h}$. Significant cell deaths were noted 
for all primary cell cultures, although PTX alone was more cytotoxic than PTX-loaded PHB-co-3HV NPs [63].

To achieve targeted delivery, Kilicay et al. demonstrated that ETP-loaded folic acid (FA)-functionalized poly(3-hydroxybutyrate-co-3-hydroxyhexanoate) (ETP/FA-PHBco-HHX-NPs) were more cytotoxic against HeLa cells compared to non-FA conjugated nanoparticles (ETP-PHB-co-HHX-NPs). Cell deaths of $44.2 \%$ and $30.1 \%$ were observed for ETP/FA-PHB-co-HHX-NPs and ETP-PHB-co-HHX-NPs when treated with equal drug concentrations [34]. This observation could be due to the selective targeting of folate ligands to cancer cells with overexpressed folic acid receptors. In another study, doxorubicin (DOX)-loaded FA-conjugated poly(3-hydroxybutyrate-co-3-hydroxyoctanoate) [P(HB-coHO)] nanoparticles (DOX/FA PHB-co-HO-NPs) were significantly more cytotoxic towards HeLa cells compared to non-FA NPs. The $\mathrm{IC}_{50}$ of DOX/FA PHB-co-HO-NPs and non-FA NPs were $0.87 \mu \mathrm{M}$ and $27.53 \mu \mathrm{M}$, respectively, which demonstrated that the potency of killing HeLa cells increased thirtyfold when an active targeting ligand was added [42]. A prolonged drug release pattern was noticed whereby almost $50 \%$ of DOX was released after 5 days.

In another study, Sasikumar and Ayyasamy also observed that the release behaviour of DOX encapsulated within PHB nanoparticles using a nanoprecipitation technique followed a slow, sustained release curve [65]. Owing to the sustained DOX release, selective cancer targeting, and higher internalization rate, the reduction of tumour volume for HeLa bearing BALB/c nude mice was comparably higher for DOX/FA PHB-co-HO-NPs (final tumour volume: $\left.178.91 \pm 17.43 \mathrm{~mm}^{3}\right)$ compared to a normal saline group $\left(542.58 \pm 45.19 \mathrm{~mm}^{3}\right)$ [42]

A genetically modified PHA synthase co-expressed with a PHB chain fused with a specific ligand (Cys-Asp-Cys-Arg-Gly-Asp-Cys-Phe-Cys, RGD4C) was conjugated onto the surface of PHB nanoparticles to provide the nanoformulation with a targeted delivery towards cancer cells $[51,66]$. The authors ligated the chemically synthesized oligonucleotides encoding the RGD4C peptide upstream of the phaC gene to express the PHA chain fused with the RGD4C ligand. The functionalized PHB nanoparticle displayed a specific affinity towards MDA-MB-231 breast cancer cells, thus confirming the successful surface modification of a PHB nanoparticle with an active ligand [51]. In another study, phaP-fused human a1-acid glycoprotein (hAGP) or human epidermal growth factor (hEGF) ligands were attached to the surface of PHB-co-3HHx nanoparticles loaded with RBITC as a model drug, and were then evaluated in vitro against macrophage and hepatocellular carcinoma cells (Bel7402) [52]. Strong fluorescence signals were detected in macrophage cells after treatment with rhAGP-phaP-PHA nanoparticles, indicating that mannosereceptor mediated endocytosis was achieved with ligand-targeted recognition. Similarly, for hepatocellular carcinoma cell Bel7402 with rich EGF receptors, the in vivo delivery of nanoparticles to tumour cell-bearing mice revealed the specific recognition of hEGFphaP-PHA nanoparticles towards tumour sites with little internalization in lung and liver tissues [52].

The use of phosphoinositide-3-kinase (PI3K) and mTOR inhibitors represent a promising approach in cancer therapy. The P13Ks belong to the family of lipid kinases that have crucial regulatory functions in cellular processes such as cell growth and survival [67]. Meanwhile, mTOR is a serine and threonine kinase that acts as sensor for energy, nutrients, and redox in metabolisms [68]. In cancer particularly, the P13K-AKT-mTOR pathway is often dysregulated and abnormally activated in human cancers in several mechanisms involving receptor tyrosine kinases (RTKs), Akt/PKB, tensin homolog (PTEN), MTOR, and other oncogene suppressor genes [69-72]. Several studies have demonstrated that TGX221, a PI3K p110 $\beta$ selective inhibitor, is capable of inhibiting the growth of glioblastoma cells [73,74], prostate cancer [75], and PTEN-deficient cancer cell lines [76]. Even though it has been used as a p110 $\beta$-selective inhibitor, the clinical trial outcomes were unsatisfactory owing to its low solubility and short half-life [39]. In a study by Lu et al., the encapsulation of TGX-221 in PHA nanoparticles significantly blocked the growth of PC3, BT-474, and HCT-116 cells compared to free TGX-221 [39]. The authors also showed that drug release 
could be altered with the incorporation of different PHA monomers depending on the crystallinity of the polymer. For instance, about $76 \%$ of drug was released within $32 \mathrm{~h}$ using a PHB-co-HHx nanoparticle compared to a $42 \%$ release for a PHB homopolymer nanoparticle [39].

In another study, a PEG200-end-capped PHBHHx (PHBHHxPEG) nanoparticle, a novel hybrid copolymer, was prepared via an emulsification-solvent evaporation method [40]. These nanoparticles, which have an average diameter of $200 \mathrm{~nm}$, were loaded with rapamycin which is a natural inhibitor of mammalian target of rapamycin (mTOR) [40]. Like other studies, the hydrophobicity of the polymeric material caused the nanoparticles to be degraded at a slower rate. Therefore, the sustained release of rapamycin was achieved for almost 10 days. An almost 50\% cell inhibition of prostate cancer cells was noted when the cells were treated with $100 \mu \mathrm{g} / \mathrm{mL}$ rapamycin-loaded PHBHHxPEG nanoparticles for $24 \mathrm{~h}$. The anti-proliferation effect for rapamycin-loaded PHBHHxPEG nanoparticles were also stronger compared to free rapamycin [40].

PHA nanoparticles were also employed to encapsulate a photosensitizer compound (PS) for photodynamic therapy (PDT) in the treatment of cancer. PDT involves the combination of light and a PS to destroy abnormal tissues while exerting negligible damage towards surrounding healthy cells [77]. Similar to many other hydrophobic molecules, PS compounds suffer from stability issues due to their limited solubility in aqueous media. As demonstrated by Pramual et al., the delivery of 5,10,15,20-tetrakis(4-hydroxy-phenyl)-21H, $23 \mathrm{H}$-porphine (pTHPP) using PHB-co-HV nanoparticles increased the in vitro photocytotoxicity against HT-29 colon cancer cells with respect to incubation time and drug concentration [48]. Cell death of up to $94 \%$ was noted when the cancer cells were exposed to $8 \mu \mathrm{g} / \mathrm{mL}$ of pTHPP-loaded PHB-co-HV nanoparticles. The faster photocytotoxicity effect compared to pTHPP-loaded NPs was probably due to a higher passive diffusion of free DMSO-solubilized pTHPP molecules [48].

PHB-coated magnetic nanoparticles were prepared via co-precipitation of iron salts $\left(\mathrm{Fe}^{2+}\right.$ and $\left.\mathrm{Fe}^{3+}\right)$, and PHB molecules that were physically loaded with doxorubicin (DOX) were at least 2.5 times more cytotoxic against DOX-resistant MCF-7 cells compared to the free drug [78]. Drugs were released at a higher concentration at acidic conditions, mimicking the endosomal $\mathrm{pH}$ rather than physiological conditions ( $\mathrm{pH}$ 7.2). Approximately $50 \%$ of the DOX was released at $\mathrm{pH} 4.5$ after $9 \mathrm{~h}$ of incubation. In comparison, only $35 \%$ of the drugs were released at $\mathrm{pH} 7.2$ [78]. In another study, similar results were found whereby ETP-loaded PHB-coated magnetic nanoparticles displayed significantly higher cytotoxic effects against HeLa cell lines compared to non-magnetic PHB nanoparticles [56]. A combined delivery of siRNA and ETP-loaded PHB-coated magnetic nanoparticles effectively downregulated the expression of multidrug resistance-associated protein 1 (MRP-1) in MCF-7/1000-etoposide resistance cells [79].

The delivery of microRNAs (miRNAs) to regulate the expression of pivotal genes involved in tumorigenesis and progression is another strategy employed in cancer treatment. For the treatment of prostate cancer, miR-124 is designed to modulate the expression of carnitine palmitoyltransferase 1A (CPT1A), which impairs the ability of cancer cells to metabolize lipid substrates. Recently, cationic polyethyleneimine-functionalized PHB nanoparticles (PEI/PHB-NPs) were utilized as a carrier to deliver miR-124 into prostate cancer cells (PC3) [80]. The delivered miR-124 interfered with the expression of CPT1A and reduced malignant cell functionality (i.e., proliferation, motility, and colony formation) [80]. Meanwhile, the delivery of miR-128 using PHB-co-PEI nanoparticles led to a $24.5 \%$ cell death in U87 glioblastoma cells [81], which was in accord with other findings showing that miR-128 expressions selectively downregulated glioblastoma cells compared to normal brain cells $[82,83]$.

\subsection{Treatment of Infectious Diseases}

Many studies have explored the suitability of non-woven PHB nanofibers incorporated with various antibiotics (gentamicin sulfate, kanamycin sulphate, levofloxacin) prepared 
via electrospinning for antibacterial and biomedical applications [84-86]. The nanofibers prepared via electrospinning, an electrostatic fiber fabrication technique, are usually within the size range of 10-10,000 $\mathrm{nm}$ and have improved mechanical properties [87]. In addition to that, electrospun nanofibers can mimic nanoscale properties as well as stimulate the functions of a native extracellular matrix [86]. In vitro data of antibiotic-loaded PHB nanofibers demonstrated promising antibacterial activity based on good inhibition zones against Micrococcus luteus, Serratia marcescens, Escherichia coli [85], and Staphylococcus aureus [86]. Nanocomposites of PHBV, nanodiamond (nD), and nanohydroxyapatite (nHA) prepared using the injection molding technique enabled the sustained release of antibiotics for 22 days. The antibiotics were still active even after being exposed to high heat $\left(178^{\circ} \mathrm{C}\right)$ during the molding process [88].

However, with the emergence of antibiotic resistance, much attention has been diverted to the search for alternative antimicrobial agents such as metal-based agents and natural products [89-97]. Mukheem and groups proposed 2D nanomaterials (graphene, silver, boron nitride, molybdenum disulfide) as alternatives to antibiotics for the treatment of infections [92-94]. Graphene-decorated silver nanoparticles (GAg) incorporated into nanofibers of $\mathrm{P}(\mathrm{HB}-\mathrm{co}-\mathrm{HHx})$ were more effective compared to $\mathrm{PHA} /$ graphene oxide in killing S. aureus and E. coli [94]. Similarly, hexagonal boron nitride encapsulated within PHA/chitosan nanocomposites [92] and two-dimensional molybdenum disulfide (2D MoS2) nanoparticles [93] showed significant antibacterial activity against multidrugresistant $E$. coli and methicillin-resistant $S$. aureus (MRSA).

Xing et al. reported the in vitro antibacterial activity of $\mathrm{P}(\mathrm{HB}-\mathrm{co}-\mathrm{HV})$ nanofibers loaded with silver nanoparticles (AgNPs) with a diameter of 5-13 nm [98]. The authors showed that of $\mathrm{P}(\mathrm{HB}-\mathrm{co}-\mathrm{HV})$ nanofibers had negligible antibacterial activity against Staphylococcus aureus and Klebsiella pneumoniae. However, the growth of both bacteria was completed inhibited for the AgNPs containing the nanofibers [98]. AgNPs embedded onto electrospun PHB nanocomposites were also virucidal against the murine norovirus (MNV) while still maintaining the nanocomposite's optimal properties [99]. These findings implied that a customized application for packaging and contact surface industries for the eradication of viral and bacterial contamination could be possible with the proposed formulation. The compounding of a PHA nanocomposite with long alkyl chain quaternary salt (LAQ)-functionalized graphene oxide (GO-g-LAQ) improved the applications of PHA as a packaging material as denoted with a reduced oxygen permeation. Additionally, the PHA/GO-g-LAQ nanocomposites exhibited $99.9 \%$ antibacterial activity against Gram-negative and Gram-positive bacteria [97].

In a recent study, the incorporation of nitric oxide (NO) donor S-nitrosoglutathione (GSNO) onto PHB/PLA nanofibers exhibited dual antibacterial and anti-thrombotic activity [100]. The NO released from nanofibers was effective in reducing the number of attached S. aureus cells and platelet adhesion by approximately $80 \%$ and $65 \%$, respectively [100]. Li et al. developed a stimuli-triggered biocide-loaded PHA-based nanofiber with a core-shell structure [101]. This formulation was designed to prevent undesirable biocide release in a physiological environment in the absence of bacteria [101]. Moreover, the authors demonstrated that the core-shell PHA-based nanofibers effectively released biocide in the presence of $P$. aeruginosa, resulting in the attenuation of bacterial growth [101].

Besides being a carrier of antimicrobial agents, a PHA nanocomposite was also developed as a biosensor for the quantitative detection of artemisinin in body fluids [95]. Artemisinin is established in the treatment of malaria and other diseases caused by highly resistant microorganisms. The PHA/gold nanoparticle mounted onto an indium-tin oxide glass plate was surface absorbed with a horseradish peroxidase enzyme to monitor the electro-catalytic reduction of artemisinin. The sensitivity and detection of this analytical method were as low as $3.5 \mathrm{ng} / \mathrm{mL}$, which was much effective compared to other quantitative detection methods such as high-performance liquid chromatography (HPLC) and gas chromatography (GC) [95]. 


\subsection{Other Applications}

Peng et al. explored the use of a novel PHB nanoparticle loaded with recombinant human BMP-2 and an amphiphilic phospholipid (BPC-PHB NP) for long-term osteogenic differentiation [102]. The formulation achieved both rapid-acting and long-lasting actions of osteogenic differentiation as seen with the short initial burst release in the first $24 \mathrm{~h}$ followed by a steady increase of BMP-2 release for up to 20 days [102]. A novel block copolymer of PHB and PEG conjugated with deoxycholic acid was prepared via transesterification and enhanced cellular internalization and intestinal permeability. Therefore, Chaturvedi et al. attempted to develop an insulin formulation with improved oral bioavailability using this nanocomposite as the delivery vehicle [103]. Extended serum levels of insulin after oral administration were observed for insulin-loaded DOCA-PHB-PEG NPs, which is approximately $12 \%$ of the relative bioavailability [103].

\section{Challenges and Author's Perspective}

Biocompatibility and cytotoxicity are major concerns for PHA applications as medical tools. Although the biocompatibility of PHAs is well-understood, the cytotoxicity should be minimized with caution by ensuring the purity of PHA employed in medical tool development. Repeated dissolving and precipitation of PHA in downstream processes of microbial PHA production systems are needed to guarantee the high purity of PHA [104]. However, residual organic solvents such as chloroform for PHA extraction and methanol for PHA precipitation could be a health threat if not removed completely prior to in vivo applications. The cytotoxicity of chloroform is attributed to its ability to modify the properties of the cell membrane lipid matrix that may lead to cell death [105-107]. Methanol is cytotoxic due to its inhibitory effect on cell proliferation at a concentration of more than $10 \%$ [108]. Complete removal can be achieved by ensuring the complete evaporation of residual solvents from the PHA pellets, considering the volatile nature of these solvents, followed by proper washing. Apart from chemical extraction, PHA can be extracted biologically by feeding PHA-harboring microbial cells to a mealworm species (Tenebrio molitor) that discharges PHA as waste [109].

Microbial production of PHA involves mainly Gram-negative bacteria, with Cupriavidus necator (also known as Ralstonia eutropha) as the standard PHA-producing bacteria among them. The endotoxins constitute lipopolysaccharides (LPS), heat-resistant components located in the outer cell membrane of Gram-negative bacteria, which are responsible for inflammatory reactions in biomedical applications of biomaterials. LPS are liberated during PHA extraction steps, where the cell biomass is lysed. The LPS then contaminates the resulting PHA and are carried along to the precipitation step, thus remaining on the resulting PHA pellets [104,110-112]. The proper and efficient removal of endotoxins is necessary to assure in vivo applicability, and common removal methods include using sodium hydroxide or hydrogen peroxide $[113,114]$. Alternatively, endotoxin-free PHA can be obtained by using Gram-positive bacteria for production instead, owing to the inability of Gram-positive bacteria to produce LPS. Bacillus is a popular choice, given its promising PHA yield and less stringent requirements for fermentation conditions $[115,116]$.

Although PHAs are biocompatible, some of their physicochemical properties hinder wider use in several applications. Poly(3-hydroxybutyrate) $[\mathrm{P}(3 \mathrm{HB})]$ and Poly(3hydroxybutyrate-co-3-hydroxyvalerate) $[\mathrm{P}(3 \mathrm{HB}-\mathrm{co}-3 \mathrm{HV})]$ are the most studied PHAs for numerous biomedical applications [25,117-120]. The employment of homopolymer $\mathrm{P}(3 \mathrm{HB})$ as a drug delivery device is discouraging due to its inherently poor thermal stability that leads to limited processibility and uncontrollable drug release kinetics [121]. The incorporation of a 3-hydroxyvalerate (3HV) monomer provides better flexibility and strength, with reduced chain packing and toughness in the resulting copolymeric $\mathrm{P}(3 \mathrm{HB}-\mathrm{co}-3 \mathrm{HV})$ [122-126]. $\mathrm{P}(3 \mathrm{HB}-\mathrm{co}-3 \mathrm{HV})$ is attractive as a drug delivery agent, as the higher molar fraction of $3 \mathrm{HV}$ in the copolymer contributes to a more amorphous structure that favors drug release $[127,128]$. Additionally, the incorporation of a second or even third monomer to form a copolymer or terpolymer also leads to lower crystallinity which is a desirable charac- 
teristic for PHA-based implants that require sufficient biodegradability [129]. In addition to biodegradability, enhanced mechanical properties can also be achieved to provide support in arteries as a stent in angioplasty [130]. However, PHAs have poor compatibility with therapeutic agents, which results in a low encapsulation efficiency due to their hydrophobicity, as mentioned earlier. Incorporation of hydrophilicity is generally done by functionalizing PHA with polar functional groups, or by block/graft copolymerization of PHA with hydrophilic components such as poly(ethylene glycol) $[49,131]$.

Despite the excellent potential of PHAs, their high selling price is a major drawback when considering their use in medical applications. As the carbon sources employed in PHA manufacturing contribute to $30-40 \%$ of the overall production costs, the employment of waste in substitution of defined carbon sources was attempted to make PHA more affordable and economically competitive $[132,133]$. With increasing emphasis on sustainability, waste plant oils are gaining great interest [134]. One concern in using such PHAs for biomedical applications is that the residual oils will adhere to bacterial biomass, then be carried forward to subsequent downstream processing. Residual oil removal is usually carried out using non-polar organic solvents such as hexane, which has a polarity index of 0.1 . The cell biomass must be washed repeatedly with clean water after primary washing with solvents for complete removal $[135,136]$. Alternately, residual oil removal can also be done using supercritical $\mathrm{CO}_{2}$ and $\mathrm{CO}_{2}$-expanded ethanol. The supercritical $\mathrm{CO}_{2}$ method has been shown to remove impurities of more than $70 \mathrm{wt} \%$ from $\mathrm{P}(3 \mathrm{HB})$. In contrast, more than $93 \mathrm{wt} \%$ of residual oils were removed by adding a small volume of ethanol in the presence of $\mathrm{CO}_{2}$, which lowered the pressure requirement for the oil removal process [137]. As $\mathrm{CO}_{2}$ and ethanol are easily recyclable and relatively harmless, the employment of organic and hazardous solvents can be minimized.

Since the discovery of PHAs in 1888 by Martinus W. Beijerinck, the polymers have been extensively studied for the last eight decades due to academic interest [138]. The introduction of eco-friendly bio-based products as alternatives to conventional plastics brought the term 'bioplastics' to public attention. Although PHAs have generated a lot of interest in the last few decades due to their material properties, biocompatibility, and sustainability, the selling price of PHAs is still the main determining factor for commercialization [139]. The development of PHA production strategies is a continuous effort to bring about a higher PHA yield and economic attraction. Designing, evaluating, and optimizing PHA-based formulations for pharmaceutical and therapeutic applications still require more studies before their wide implementation in pharmaceutical industries due to the disadvantages resulting from their material properties $[140,141]$. Although there is still much to be explored, emerging knowledge is turning PHAs into convenient, highperformance, and economically competitive polymers that can be widely accepted and implemented for medication in the foreseeable future.

\section{Conclusions}

PHAs are an outstanding group of bioplastics renowned for their biocompatibility, biodegradability, ease of modification, ability to encapsulate drugs, as well their impressive pharmacokinetics and pharmacodynamics that surpass those of free drug therapy or other polymeric nanocarriers. PHA nanocarriers are also superior in the sense that they can degrade naturally into components that are nontoxic to the human body. PHA nanocarriers can be formulated using a wide range of techniques, such as the immensely popular emulsion solvent evaporation methods (oil-in-water, single emulsion, and water-in-oilin-water double emulsion), nanoprecipitation, dialysis, and in situ polymerization. PHA nanocarriers are commonly utilized in tissue engineering applications and even in fighting infections, with antibiotics being incorporated into PHA nanocarriers to improve the effectiveness of treatment. In cancer therapy, PHA nanocarriers are advantageous because the hydrophobic nature of the polymer aids in a higher drug load and a slow, controlled drug release. 
Unfortunately, the hydrophobicity of PHA can be undesirable when it limits solubility, but this is often countered by functionalization with hydrophilic substances. In a similar way, copolymerization and terpolymerization have been convenient solutions to combat certain PHAs' poor physical properties like thermal instability. Though PHAs themselves are non-immunogenic, certain environmentally unfriendly organic solvents used during their production, such as chloroform and methanol, can contribute to their cytotoxicity. A remedy for this would be proper washing and endotoxin removal steps or opting out of said chemicals in favor of biological extraction methods. Another major disadvantage of PHAs lies in their high production costs; however, using waste materials as carbon sources tends to lower such costs significantly.

All in all, despite the stagnation of PHA nanocarriers in clinical trials of drug delivery applications, they are undoubtedly a move in the right direction. Though many solutions have been discovered to overcome obstacles in their path, further research will always lend a helping hand towards the promisingly bright future of PHA nanocarriers in effective drug delivery systems.

Author Contributions: Conceptualization, T.P., and P.P.; writing — first draft, abstract, introduction, conclusion, P.P.; writing —-formulations, T.P.; writing-applications, W.-H.L. and C.-Y.L.; writingchallenges and author's perspective-H.S.J.W.; illustrations, H.S.J.W. and T.P.; writing-review and editing, P.P.; supervision, T.P. All authors have read and agreed to the published version of the manuscript.

Funding: The authors would like to thank the Ministry of Higher Education (MOHE), Malaysia, for the Fundamental Research Grant Scheme (FRGS/1/2018/SKK09/USM/03/1). Priyanka Prakash would like to thank the Institute of Postgraduate Studies (IPS) of Universiti Sains Malaysia (USM) for their financial support in the form of the Graduate Student Financial Assistance (Gra-ASSIST) scheme.

Data Availability Statement: Data sharing is not applicable for this review.

Conflicts of Interest: The authors declare no conflict of interest.

\section{References}

1. Jain, K.K. Drug Delivery Systems an Overview. Methods Mol. Biol. 2008, 437, 1-50. [PubMed]

2. Maiti, S.; Sen, K.K. Introductory Chapter: Drug Delivery Concepts. In Advanced Technology for Delivering Therapeutics; Maiti, S., Sen, K.K., Eds.; InTech: London, UK, 2017.

3. Neubert, R.H.H. Potentials of New Nanocarriers for Dermal and Transdermal Drug Delivery. Eur. J. Pharm. Biopharm. 2011, 77, 1-2. [CrossRef] [PubMed]

4. Jeevanandam, J.; Barhoum, A.; Chan, Y.S.; Dufresne, A.; Danquah, M.K. Review on Nanoparticles and Nanostructured Materials: History, Sources, Toxicity and Regulations. Beilstein J. Nanotechnol. 2018, 9, 1050-1074. [CrossRef] [PubMed]

5. Rizvi, S.A.A.; Saleh, A.M. Applications of Nanoparticle Systems in Drug Delivery Technology. Saudi Pharm. J. 2018, 26, 64-70.

6. Mirza, A.Z.; Siddiqui, F.A. Nanomedicine and Drug Delivery: A Mini Review. Int. Nano Lett. 2014, 4, 94. [CrossRef]

7. Ud Din, F.; Aman, W.; Ullah, I.; Qureshi, O.S.; Mustapha, O.; Shafique, S.; Zeb, A. Effective Use of Nanocarriers as Drug Delivery Systems for the Treatment of Selected Tumors. Int. J. Nanomed. 2017, 12, 7291-7309. [CrossRef]

8. De Villiers, M.M.; Aramwit, P.; Kwon, G.S. Nanotechnology in Drug Delivery; de Villiers, M.M., Aramwit, P., Kwon, G.S., Eds.; Springer: New York, NY, USA, 2009. [CrossRef]

9. Scicluna, M.C.; Vella-Zarb, L. Evolution of Nanocarrier Drug-Delivery Systems and Recent Advancements in Covalent Organic Framework-Drug Systems. ACS Appl. Nano Mater. 2020, 3, 3097-3115. [CrossRef]

10. Tan, G.-Y.A.; Chen, C.-L.; Li, L.; Ge, L.; Wang, L.; Razaad, I.; Li, Y.; Zhao, L.; Mo, Y.; Wang, J.-Y. Start a Research on Biopolymer Polyhydroxyalkanoate (PHA): A Review. Polymers 2014, 6, 706-754. [CrossRef]

11. Kathiraser, Y.; Aroua, M.K.; Ramachandran, K.B.; Tan, I.K.P. Chemical Characterization of Medium-Chain-Length Polyhydroxyalkanoates (PHAs) Recovered by Enzymatic Treatment and Ultrafiltration. J. Chem. Technol. Biotechnol. 2007, 82, 847-855. [CrossRef]

12. Dhandayuthapani, B.; Yoshida, Y.; Maekawa, T.; Kumar, D.S. Polymeric Scaffolds in Tissue Engineering Application: A Review. Int. J. Polym. Sci. 2011, 2011, 290602. [CrossRef]

13. Griffin, G. (Ed.) Chemistry and Technology of Biodegradable Polymers, 1994th ed.; Chapman and Hall: London, UK, 1993.

14. Nigmatullin, R.; Thomas, P.; Lukasiewicz, B.; Puthussery, H.; Roy, I. Polyhydroxyalkanoates, a Family of Natural Polymers, and Their Applications in Drug Delivery. J. Chem. Technol. Biotechnol. 2015, 90, 1209-1221. [CrossRef]

15. Shrivastav, A.; Kim, H.-Y.; Kim, Y.-R. Advances in the Applications of Polyhydroxyalkanoate Nanoparticles for Novel Drug Delivery System. Biomed Res. Int. 2013, 2013, 581684. [CrossRef] 
16. Li, Z.; Yang, J.; Loh, X.J. Polyhydroxyalkanoates: Opening Doors for a Sustainable Future. NPG Asia Mater. 2016,8 , e265. [CrossRef]

17. Kourmentza, C.; Plácido, J.; Venetsaneas, N.; Burniol-Figols, A.; Varrone, C.; Gavala, H.N.; Reis, M.A.M. Recent Advances and Challenges towards Sustainable Polyhydroxyalkanoate (PHA) Production. Bioengineering 2017, 4, 55. [CrossRef]

18. National Cancer Institute. Cancer and Nanotechnology; National Cancer Institute: Rockville, MD, USA, 2020.

19. Awasthi, R.; Roseblade, A.; Hansbro, P.M.; Rathbone, M.J.; Dua, K.; Bebawy, M. Nanoparticles in Cancer Treatment: Opportunities and Obstacles. Curr. Drug Targets 2018, 19, 1696-1709. [CrossRef] [PubMed]

20. Aghebati-Maleki, A.; Dolati, S.; Ahmadi, M.; Baghbanzhadeh, A.; Asadi, M.; Fotouhi, A.; Yousefi, M.; Aghebati-Maleki, L. Nanoparticles and Cancer Therapy: Perspectives for Application of Nanoparticles in the Treatment of Cancers. J. Cell. Physiol. 2020, 235, 1962-1972. [CrossRef] [PubMed]

21. Babu, A.; Templeton, A.K.; Munshi, A.; Ramesh, R. Nanoparticle-Based Drug Delivery for Therapy of Lung Cancer: Progress and Challenges. J. Nanomater. 2013, 2013, 14. [CrossRef]

22. Lu, X.-Y.; Wu, D.-C.; Li, Z.-J.; Chen, G.-Q. Polymer Nanoparticles. Prog. Mol. Biol. Transl. Sci. 2011, 104, 299-323. [PubMed]

23. Blanco, F.G.; Hernández, N.; Rivero-Buceta, V.; Maestro, B.; Sanz, J.M.; Mato, A.; Hernández-Arriaga, A.M.; Prieto, M.A. From Residues to Added-Value Bacterial Biopolymers as Nanomaterials for Biomedical Applications. Nanomaterials 2021, $11,1492$. [CrossRef]

24. Elmowafy, E.; Abdal-Hay, A.; Skouras, A.; Tiboni, M.; Casettari, L.; Guarino, V. Polyhydroxyalkanoate (PHA): Applications in Drug Delivery and Tissue Engineering. Expert Rev. Med. Devices 2019, 16, 467-482. [CrossRef]

25. Nobes, G.A.; Marchessault, R.H.; Maysinger, D. Polyhydroxyalkanoates: Materials for Delivery Systems. Drug Deliv. 1998, 5, 167-177. [CrossRef] [PubMed]

26. Michalak, M.; Kurcok, P.; Hakkarainen, M. Polyhydroxyalkanoate-Based Drug Delivery Systems: Polyhydroxyalkanoate-Based Drug Delivery Systems. Polym. Int. 2017, 66, 617-622. [CrossRef]

27. Puppi, D.; Pecorini, G.; Chiellini, F. Biomedical Processing of Polyhydroxyalkanoates. Bioengineering 2019, 6, 108. [CrossRef]

28. Rao, J.P.; Geckeler, K.E. Polymer Nanoparticles: Preparation Techniques and Size-Control Parameters. Prog. Polym. Sci. 2011, 36, 887-913. [CrossRef]

29. Babinot, J.; Guigner, J.-M.; Renard, E.; Langlois, V. A Micellization Study of Medium Chain Length Poly(3-Hydroxyalkanoate)Based Amphiphilic Diblock Copolymers. J. Colloid Interface Sci. 2012, 375, 88-93. [CrossRef] [PubMed]

30. Iqbal, M.; Zafar, N.; Fessi, H.; Elaissari, A. Double Emulsion Solvent Evaporation Techniques Used for Drug Encapsulation. Int. J. Pharm. 2015, 496, 173-190. [CrossRef]

31. Staff, R.H.; Landfester, K.; Crespy, D. Recent Advances in the Emulsion Solvent Evaporation Technique for the Preparation of Nanoparticles and Nanocapsules. In Hierarchical Macromolecular Structures: 60 Years after the Staudinger Nobel Prize II; Springer: Cham, Switzerland, 2013; pp. 329-344.

32. Hu, J.; Wang, M.; Xiao, X.; Zhang, B.; Xie, Q.; Xu, X.; Li, S.; Zheng, Z.; Wei, D.; Zhang, X. A Novel Long-Acting Azathioprine Polyhydroxyalkanoate Nanoparticle Enhances Treatment Efficacy for Systemic Lupus Erythematosus with Reduced Side Effects. Nanoscale 2020, 12, 10799-10808. [CrossRef] [PubMed]

33. Kilicay, E.; Karahaliloglu, Z.; Hazer, B.; Tekin, I.Ö.; Denkbas, E.B. Concanavaline A Conjugated Bacterial Polyester-Based PHBHHx Nanoparticles Loaded with Curcumin for Breast Cancer Therapy. J. Microencapsul. 2016, 33, 274-285. [CrossRef] [PubMed]

34. Kılıçay, E.; Demirbilek, M.; Türk, M.; Güven, E.; Hazer, B.; Denkbas, E.B. Preparation and Characterization of Poly(3Hydroxybutyrate-Co-3-Hydroxyhexanoate) (PHBHHX) Based Nanoparticles for Targeted Cancer Therapy. Eur. J. Pharm. Sci. 2011, 44, 310-320. [CrossRef] [PubMed]

35. Shah, M.; Ullah, N.; Choi, M.H.; Kim, M.O.; Yoon, S.C. Amorphous Amphiphilic P(3HV-Co-4HB)-b-MPEG Block Copolymer Synthesized from Bacterial Copolyester via Melt Transesterification: Nanoparticle Preparation, Cisplatin-Loading for Cancer Therapy and in Vitro Evaluation. Eur. J. Pharm. Biopharm. 2012, 80, 518-527. [CrossRef]

36. Piddubnyak, V.; Kurcok, P.; Matuszowicz, A.; Głowala, M.; Fiszer-Kierzkowska, A.; Jedliński, Z.; Juzwa, M.; Krawczyk, Z. Oligo-3-Hydroxybutyrates as Potential Carriers for Drug Delivery. Biomaterials 2004, 25, 5271-5279. [CrossRef] [PubMed]

37. Michalak, M.; Marek, A.A.; Zawadiak, J.; Kawalec, M.; Kurcok, P. Synthesis of PHB-Based Carrier for Drug Delivery Systems with PH-Controlled Release. Eur. Polym. J. 2013, 49, 4149-4156. [CrossRef]

38. Masood, F. Polymeric Nanoparticles for Targeted Drug Delivery System for Cancer Therapy. Mater. Sci. Eng. C Mater. Biol. Appl. 2016, 60, 569-578. [CrossRef] [PubMed]

39. Lu, X.-Y.; Ciraolo, E.; Stefenia, R.; Chen, G.-Q.; Zhang, Y.; Hirsch, E. Sustained Release of PI3K Inhibitor from PHA Nanoparticles and in Vitro Growth Inhibition of Cancer Cell Lines. Appl. Microbiol. Biotechnol. 2011, 89, 1423-1433. [CrossRef] [PubMed]

40. Lu, X.-Y.; Li, M.-C.; Zhu, X.-L.; Fan, F.; Wang, L.-L.; Ma, J.-G. Microbial Synthesized Biodegradable PHBHHxPEG Hybrid Copolymer as an Efficient Intracellular Delivery Nanocarrier for Kinase Inhibitor. BMC Biotechnol. 2014, 14, 4. [CrossRef] [PubMed]

41. Babos, G.; Rydz, J.; Kawalec, M.; Klim, M.; Fodor-Kardos, A.; Trif, L.; Feczkó, T. Poly(3-Hydroxybutyrate)-Based Nanoparticles for Sorafenib and Doxorubicin Anticancer Drug Delivery. Int. J. Mol. Sci. 2020, 21, 7312. [CrossRef]

42. Zhang, C.; Zhao, L.; Dong, Y.; Zhang, X.; Lin, J.; Chen, Z. Folate-Mediated Poly(3-Hydroxybutyrate-Co-3-Hydroxyoctanoate) Nanoparticles for Targeting Drug Delivery. Eur. J. Pharm. Biopharm. 2010, 76, 10-16. [CrossRef] [PubMed] 
43. Rezaie Shirmard, L.; Bahari Javan, N.; Khoshayand, M.R.; Kebriaee-Zadeh, A.; Dinarvand, R.; Dorkoosh, F.A. Nanoparticulate Fingolimod Delivery System Based on Biodegradable Poly (3-Hydroxybutyrate-Co-3-Hydroxyvalerate) (PHBV): Design, Optimization, Characterization and in-Vitro Evaluation. Pharm. Dev. Technol. 2017, 22, 860-870. [CrossRef] [PubMed]

44. Han, F.Y.; Thurecht, K.J.; Whittaker, A.K.; Smith, M.T. Bioerodable PLGA-Based Microparticles for Producing Sustained-Release Drug Formulations and Strategies for Improving Drug Loading. Front. Pharmacol. 2016, 7, 185. [CrossRef]

45. Pignatello, R.; Impallomeni, G.; Cupri, S.; Puzzo, G.; Curcio, C.; Rizzo, M.G.; Guglielmino, S.; Ballistreri, A. Unsaturated Poly(Hydroxyalkanoates) for the Production of Nanoparticles and the Effect of Cross-Linking on Nanoparticle Features. Materials 2019, 12, 868. [CrossRef]

46. Eke, G.; Kuzmina, A.M.; Goreva, A.V.; Shishatskaya, E.I.; Hasirci, N.; Hasirci, V. In Vitro and Transdermal Penetration of PHBV Micro/Nanoparticles. J. Mater. Sci. Mater. Med. 2014, 25, 1471-1481. [CrossRef]

47. Masood, F.; Chen, P.; Yasin, T.; Fatima, N.; Hasan, F.; Hameed, A. Encapsulation of Ellipticine in Poly-(3-Hydroxybutyrate-Co-3Hydroxyvalerate) Based Nanoparticles and Its in Vitro Application. Mater. Sci. Eng. C Mater. Biol. Appl. 2013, 33, 1054-1060. [CrossRef] [PubMed]

48. Pramual, S.; Assavanig, A.; Bergkvist, M.; Batt, C.A.; Sunintaboon, P.; Lirdprapamongkol, K.; Svasti, J.; Niamsiri, N. Development and Characterization of Bio-Derived Polyhydroxyalkanoate Nanoparticles as a Delivery System for Hydrophobic Photodynamic Therapy Agents. J. Mater. Sci. Mater. Med. 2016, 27, 40. [CrossRef] [PubMed]

49. Shah, M.; Naseer, M.I.; Choi, M.H.; Kim, M.O.; Yoon, S.C. Amphiphilic PHA-MPEG Copolymeric Nanocontainers for Drug Delivery: Preparation, Characterization and in Vitro Evaluation. Int. J. Pharm. 2010, 400, 165-175. [CrossRef] [PubMed]

50. Kapoor, S.; Gupta, D.; Kumar, M.; Sharma, S.; Gupta, A.K.; Misro, M.M.; Singh, H. Intracellular Delivery of Peptide Cargos Using Polyhydroxybutyrate Based Biodegradable Nanoparticles: Studies on Antitumor Efficacy of BCL-2 Converting Peptide, NuBCP-9. Int. J. Pharm. 2016, 511, 876-889. [CrossRef]

51. Lee, J.; Jung, S.-G.; Park, C.-S.; Kim, H.-Y.; Batt, C.A.; Kim, Y.-R. Tumor-Specific Hybrid Polyhydroxybutyrate Nanoparticle: Surface Modification of Nanoparticle by Enzymatically Synthesized Functional Block Copolymer. Bioorg. Med. Chem. Lett. 2011, 21, 2941-2944. [CrossRef] [PubMed]

52. Yao, Y.-C.; Zhan, X.-Y.; Zhang, J.; Zou, X.-H.; Wang, Z.-H.; Xiong, Y.-C.; Chen, J.; Chen, G.-Q. A Specific Drug Targeting System Based on Polyhydroxyalkanoate Granule Binding Protein PhaP Fused with Targeted Cell Ligands. Biomaterials 2008, 29, 4823-4830. [CrossRef]

53. Leimann, F.V.; Cardozo Filho, L.; Sayer, C.; Araújo, P.H.H. Poly(3-Hydroxybutyrate-Co-3-Hydroxyvalerate) Nanoparticles Prepared by a Miniemulsion/Solvent Evaporation Technique: Effect of Phbv Molar Mass and Concentration. Braz. J. Chem. Eng. 2013, 30, 369-377. [CrossRef]

54. Cañadas, O.; García-García, A.; Prieto, M.A.; Pérez-Gil, J. Polyhydroxyalkanoate Nanoparticles for Pulmonary Drug Delivery: Interaction with Lung Surfactant. Nanomaterials 2021, 11, 1482. [CrossRef]

55. El-Malek, F.A.; Rofeal, M.; Farag, A.; Omar, S.; Khairy, H. Polyhydroxyalkanoate Nanoparticles Produced by Marine Bacteria Cultivated on Cost Effective Mediterranean Algal Hydrolysate Media. J. Biotechnol. 2021, 328, 95-105. [CrossRef] [PubMed]

56. Erdal, E.; Kavaz, D.; Şam, M.; Demirbilek, M.; Demirbilek, M.E.; Sağlam, N.; Denkbaş, E.B. Preparation and Characterization of Magnetically Responsive Bacterial Polyester Based Nanospheres for Cancer Therapy. J. Biomed. Nanotechnol. 2012, 8, 800-808. [CrossRef] [PubMed]

57. Di Mascolo, D.; Basnett, P.; Palange, A.L.; Francardi, M.; Roy, I.; Decuzzi, P. Tuning core hydrophobicity of spherical polymeric nanoconstructs for docetaxel delivery. Polym. Int. 2016, 65, 741-746. [CrossRef]

58. Kilicay, E.; Erdal, E.; Hazer, B.; Türk, M.; Denkbas, E.B. Antisense oligonucleotide delivery to cancer cell lines for the treatment of different cancer types. Artif. Cells Nanomed. Biotechnol. 2016, 44, 1938-1948. [CrossRef] [PubMed]

59. Chaturvedi, K.; Ganguly, K.; Kulkarni, A.R.; Nadagouda, M.N.; Stowbridge, J.; Rudzinski, W.E.; Aminabhavi, T.M. Ultra-small fluorescent bile acid conjugated PHB-PEG block copolymeric nanoparticles: Synthesis, characterization and cellular uptake. RSC Adv. 2013, 3, 7064-7070. [CrossRef]

60. Kim, H.Y.; Ryu, J.H.; Chu, C.W.; Son, G.M.; Jeong, Y.I.; Kwak, T.W.; Kim, D.H.; Chung, C.W.; Rhee, Y.H.; Kang, D.H.; et al. Paclitaxel-incorporated nanoparticles using block copolymers composed of poly(ethylene glycol)/poly(3-hydroxyoctanoate). Nanoscale Res. Lett. 2014, 9, 525. [CrossRef]

61. Pandian, S.R.K.; Deepak, V.; Nellaiah, H.; Sundar, K. PEG-PHB-glutaminase nanoparticle inhibits cancer cell proliferation in vitro through glutamine deprivation. In Vitro Cell. Dev. Biol.-Anim. 2015, 51, 372-380. [CrossRef]

62. Akbal, Ö.; Erdal, E.; Vural, T.; Kavaz, D.; Denkbaş, E.B. Comparison of protein- and polysaccharide-based nanoparticles for cancer therapy: Synthesis, characterization, drug release, and interaction with a breast cancer cell line. Artif. Cells Nanomed. Biotechnol. 2017, 45, 193-203. [CrossRef]

63. Vilos, C.; Morales, F.A.; Solar, P.; Herrera, N.S.; Nilo, F.D.G.; Aguayo, D.A.; Mendoza, H.L.; Comer, J.; Bravo, M.L.; Gonzalez, P.A.; et al. Paclitaxel-PHBV nanoparticles and their toxicity to endometrial and primary ovarian cancer cells. Biomaterials 2013, 34, 4098-4108. [CrossRef]

64. Xiong, Y.-C.; Yao, Y.-C.; Zhan, X.-Y.; Chen, G.-Q. Application of Polyhydroxyalkanoates Nanoparticles as Intracellular Sustained Drug-Release Vectors. J. Biomater. Sci. Polym. Ed. 2010, 21, 127-140. [CrossRef]

65. Sasikumar, P.; Ayyasamy, P.M. Design and Characterization of Poly-Hydroxy Butyric Acid (PHB) Based Polymeric Nanoparticles for Controlled Release of Doxorubicin for Cancer Treatment. Int. J. Curr. Microbiol. App. Sci. 2015, 4, 311-317. 
66. Kim, H.N.; Lee, J.; Kim, H.Y.; Kim, Y.R. Enzymatic synthesis of a drug delivery system based on polyhydroxyalkanoate-protein block copolymers. Chem. Commun. 2009, 46, 7104-7106. [CrossRef] [PubMed]

67. Janku, F.; Yap, T.A.; Meric-Bernstam, F. Targeting the PI3K pathway in cancer: Are we making headway? Nat. Rev. Clin. Oncology 2018, 15, 273-291. [CrossRef] [PubMed]

68. Saxton, R.A.; Sabatini, D.M. mTOR Signaling in Growth, Metabolism, and Disease. Cell 2017, 168, 960-976. [CrossRef] [PubMed]

69. Hyman, D.M.; Smyth, L.M.; Donoghue, M.T.A.; Westin, S.N.; Bedard, P.L.; Dean, E.J.; Bando, H.; El-Khoueiry, A.B.; Pérez-Fidalgo, J.A.; Mita, A.; et al. AKT Inhibition in Solid Tumors With AKT1 Mutations. J. Clin. Oncol. 2017, 35, 2251-2259. [CrossRef]

70. Kwiatkowski, D.J.; Choueiri, T.K.; Fay, A.P.; Rini, B.I.; Thorner, A.R.; de Velasco, G.; Tyburczy, M.E.; Hamieh, L.; Albiges, L.; Agarwal, N.; et al. Mutations in TSC1, TSC2, and MTOR Are Associated with Response to Rapalogs in Patients with Metastatic Renal Cell Carcinoma. Clin. Cancer Res. 2016, 22, 2445-2452. [CrossRef] [PubMed]

71. Moulder, S.; Helgason, T.; Janku, F.; Wheler, J.; Moroney, J.; Booser, D.; Albarracin, C.; Morrow, P.K.; Atkins, J.; Koenig, K.; et al. Inhibition of the phosphoinositide 3-kinase pathway for the treatment of patients with metastatic metaplastic breast cancer. Ann. Oncol. 2015, 26, 1346-1352. [CrossRef]

72. Pearson, H.B.; Li, J.; Meniel, V.S.; Fennell, C.M.; Waring, P.; Montgomery, K.G.; Rebello, R.J.; Macpherson, A.A.; Koushyar, S.; Furic, L.; et al. Identification of Pik3ca Mutation as a Genetic Driver of Prostate Cancer That Cooperates with Pten Loss to Accelerate Progression and Castration-Resistant Growth. Cancer Discov. 2018, 8, 764-779. [CrossRef]

73. Yang, X.; Yang, J.-A.; Liu, B.-H.; Liao, J.-M.; Yuan, F.; Tan, Y.-Q.; Chen, Q.-X. TGX-221 inhibits proliferation and induces apoptosis in human glioblastoma cells. Oncol. Rep. 2017, 38, 2836-2842. [CrossRef]

74. Zhao, H.-F.; Wang, J.; Jiang, H.-R.; Chen, Z.-P.; To, S.-S.T. PI3K p110ß isoform synergizes with JNK in the regulation of glioblastoma cell proliferation and migration through Akt and FAK inhibition. J. Exp. Clin. Cancer Res. 2016, 35, 78. [CrossRef]

75. Chen, R.; Zhao, Y.; Huang, Y.; Yang, Q.; Zeng, X.; Jiang, W.; Liu, J.; Thrasher, J.B.; Forrest, M.L.; Li, B. Nanomicellar TGX221 blocks xenograft tumor growth of prostate cancer in nude mice. Prostate 2015, 75, 593-602. [CrossRef]

76. Wee, S.; Wiederschain, D.; Maira, S.-M.; Loo, A.; Miller, C.; deBeaumont, R.; Stegmeier, F.; Yao, Y.-M.; Lengauer, C. PTEN-deficient cancers depend on PIK3CB. Proc. Natl. Acad. Sci. USA 2008, 105, 13057. [CrossRef]

77. Baskaran, R.; Lee, J.; Yang, S.-G. Clinical development of photodynamic agents and therapeutic applications. Biomater. Res. 2018, 22, 25. [CrossRef]

78. Yalcin, S.; Unsoy, G.; Mutlu, P.; Khodadust, R.; Gunduz, U. Polyhydroxybutyrate-coated magnetic nanoparticles for doxorubicin delivery: Cytotoxic effect against doxorubicin-resistant breast cancer cell line. Am. J. Ther. 2014, 21, 453-461. [CrossRef] [PubMed]

79. Yalcin, S.; Gündüz, U. Synthesis and biological activity of siRNA and Etoposide with magnetic nanoparticles on drug resistance model MCF-7 Cells: Molecular docking study with MRP1 enzyme. Nanomed. J. 2021, 8, 98-105.

80. Conte, R.; Valentino, A.; Di Cristo, F.; Peluso, G.; Cerruti, P.; Di Salle, A.; Calarco, A. Cationic Polymer Nanoparticles-Mediated Delivery of miR-124 Impairs Tumorigenicity of Prostate Cancer Cells. Int. J. Mol. Sci. 2020, 21, 869. [CrossRef]

81. Memari, E.; Maghsoudi, A.; Yazdian, F.; Yousefi, M.; Mohammadi, M. Synthesis of PHB-co-PEI nanoparticles as gene carriers for miR-128-encoding plasmid delivery to U87 glioblastoma cells. Colloids Surfaces A: Physicochem. Eng. Asp. 2020, 599 , 124898. [CrossRef]

82. Shan, Z.-N.; Tian, R.; Zhang, M.; Gui, Z.-H.; Wu, J.; Ding, M.; Zhou, X.-F.; He, J. miR128-1 inhibits the growth of glioblastoma multiforme and glioma stem-like cells via targeting BMI1 and E2F3. Oncotarget 2016, 7, 78813-78826. [CrossRef]

83. She, X.; Yu, Z.; Cui, Y.; Lei, Q.; Wang, Z.; Xu, G.; Xiang, J.; Wu, M.; Li, G. miR-128 and miR-149 enhance the chemosensitivity of temozolomide by Rap1B-mediated cytoskeletal remodeling in glioblastoma. Oncol. Rep. 2014, 32, 957-964. [CrossRef]

84. Amini, F.; Semnani, D.; Karbasi, S.; Banitaba, S.N. A novel bilayer drug-loaded wound dressing of PVDF and PHB/Chitosan nanofibers applicable for post-surgical ulcers. Int. J. Polym. Mater. 2018, 68, 772-777. [CrossRef]

85. Kundrat, V.; Cernekova, N.; Kovalcik, A.; Enev, V.; Marova, I. Drug Release Kinetics of Electrospun PHB Meshes. Materials 2019, 12, 1924. [CrossRef]

86. Naveen, N.; Kumar, R.; Balaji, S.; Uma, T.; Natrajan, T.; Sehgal, P. Synthesis of Nonwoven Nanofibers by Electrospinnin-A Promising Biomaterial for Tissue Engineering and Drug Delivery. Adv. Eng. Mater. 2010, 12, B380-B387. [CrossRef]

87. Zhao, X.; Niu, Y.; Mi, C.; Gong, H.; Yang, X.; Cheng, J.; Zhou, Z.; Liu, J.; Peng, X.; Wei, D. Electrospinning nanofibers of microbial polyhydroxyalkanoates for applications in medical tissue engineering. J. Appl. Polym. Sci. 2021, 59, 1994-2013. [CrossRef]

88. Neto, G.R.D.A.; Barcelos, M.V.; Ribeiro, M.E.A.; Folly, M.M.; Rodriguez, R.J.S. Formulation and characterization of a novel PHBV nanocomposite for bone defect filling and infection treatment. Mater. Sci. Eng. C 2019, 104, 110004. [CrossRef] [PubMed]

89. Kandhasamy, S.; Perumal, S.; Madhan, B.; Umamaheswari, N.; Banday, J.A.; Perumal, P.T.; Santhanakrishnan, V.P. Synthesis and Fabrication of Collagen-Coated Ostholamide Electrospun Nanofiber Scaffold for Wound Healing. ACS Appl. Mater. Interfaces 2017, 9, 8556-8568. [CrossRef]

90. Kuntzler, S.G.; de Almeida, A.C.A.; Costa, J.A.V.; de Morais, M.G. Polyhydroxybutyrate and phenolic compounds microalgae electrospun nanofibers: A novel nanomaterial with antibacterial activity. Int. J. Biol. Macromol. 2018, 113, 1008-1014. [CrossRef] [PubMed]

91. Lightfoot Vidal, S.; Rojas, C.; Bouza Padín, R.; Pérez Rivera, M.; Haensgen, A.; González, M.; Rodríguez-Llamazares, S. Synthesis and characterization of polyhydroxybutyrate-co-hydroxyvalerate nanoparticles for encapsulation of quercetin. J. Bioact. Compat. Polym. 2016, 31, 439-452. [CrossRef] 
92. Mukheem, A.; Muthoosamy, K.; Manickam, S.; Sudesh, K.; Shahabuddin, S.; Saidur, R.; Akbar, N.; Sridewi, N. Fabrication and Characterization of an Electrospun PHA/Graphene Silver Nanocomposite Scaffold for Antibacterial Applications. Materials 2018, 11, 1673. [CrossRef]

93. Mukheem, A.; Shahabuddin, S.; Akbar, N.; Anwar, A.; Sarih, N.M.; Sudesh, K.; Khan, N.; Sridewi, N. Fabrication of biopolymer polyhydroxyalkanoate/chitosan and 2D molybdenum disulfide-doped scaffolds for antibacterial and biomedical applications. Appl. Microbiol. Biotechnol. 2020, 104, 3121-3131. [CrossRef] [PubMed]

94. Mukheem, A.; Shahabuddin, S.; Akbar, N.; Miskon, A.; Sarih, N.M.; Sudesh, K.; Khan, N.A.; Saidur, R.; Sridewi, N. Boron Nitride Doped Polyhydroxyalkanoate/Chitosan Nanocomposite for Antibacterial and Biological Applications. Nanomaterials 2019, 9, 645. [CrossRef]

95. Phukon, P.; Radhapyari, K.; Konwar, B.K.; Khan, R. Natural polyhydroxyalkanoate-gold nanocomposite based biosensor for detection of antimalarial drug artemisinin. Mater. Sci. Eng. C 2014, 37, 314-320. [CrossRef]

96. Wu, C.-S.; Wang, S.-S. Bio-Based Electrospun Nanofiber of Polyhydroxyalkanoate Modified with Black Soldier Fly's Pupa Shell with Antibacterial and Cytocompatibility Properties. ACS Appl. Mater. Interfaces 2018, 10, 42127-42135. [CrossRef]

97. Xu, P.; Yang, W.; Niu, D.; Yu, M.; Du, M.; Dong, W.; Chen, M.; Jan Lemstra, P.; Ma, P. Multifunctional and robust polyhydroxyalkanoate nanocomposites with superior gas barrier, heat resistant and inherent antibacterial performances. Chem. Eng. J. 2020, 382, 122864. [CrossRef]

98. Xing, Z.-C.; Chae, W.-P.; Baek, J.-Y.; Choi, M.-J.; Jung, Y.; Kang, I.-K. In Vitro Assessment of Antibacterial Activity and Cytocompatibility of Silver-Containing PHBV Nanofibrous Scaffolds for Tissue Engineering. Biomacromolecules 2010, 11, 1248-1253. [CrossRef] [PubMed]

99. Mayorga, J.L.C.; Randazzo, W.; Fabra, M.J.; Lagaron, J.; Aznar, R.; Sánchez, G. Antiviral properties of silver nanoparticles against norovirus surrogates and their efficacy in coated polyhydroxyalkanoates systems. LWT Food Sci. Technol. 2017, 79, 503-510. [CrossRef]

100. Douglass, M.; Hopkins, S.; Pandey, R.; Singha, P.; Norman, M.; Handa, H. S-Nitrosoglutathione-Based Nitric Oxide-Releasing Nanofibers Exhibit Dual Antimicrobial and Antithrombotic Activity for Biomedical Applications. Macromol. Biosci. 2021, 21, 2000248. [CrossRef]

101. Li, W.; Cicek, N.; Levin, D.B.; Logsetty, S.; Liu, S. Bacteria-triggered release of a potent biocide from core-shell polyhydroxyalkanoate (PHA)-based nanofibers for wound dressing applications. J. Biomater. Sci. Polym. Ed. 2020, 31, 394-406. [CrossRef]

102. Peng, X.; Chen, Y.; Li, Y.; Wang, Y.; Zhang, X. A Long-Acting BMP-2 Release System Based on Poly(3-hydroxybutyrate) Nanoparticles Modified by Amphiphilic Phospholipid for Osteogenic Differentiation. BioMed Res. Int. 2016, 2016, 5878645. [CrossRef]

103. Chaturvedi, K.; Ganguly, K.; Kulkarni, A.R.; Rudzinski, W.E.; Krauss, L.; Nadagouda, M.N.; Aminabhavi, T.M. Oral insulin delivery using deoxycholic acid conjugated PEGylated polyhydroxybutyrate co-polymeric nanoparticles. Nanomedicine 2015, 10, 1569-1583. [CrossRef]

104. Volova, T.; Shishatskaya, E.; Sevastianov, V.; Efremov, S.; Mogilnaya, O. Results of biomedical investigations of PHB and PHB/PHV fibers. Biochem. Eng. J. 2003, 16, 125-133. [CrossRef]

105. Miller, K.W.; Pang, K.-Y.Y. General anaesthetics can selectively perturb lipid bilayer membranes. Nature 1976, $263,253-255$. [CrossRef]

106. Pang, K.-Y.Y.; Miller, K.W. Cholesterol modulates the effects of membrane perturbers in phospholipid vesicles and biomembranes. Biochim. Et Biophys. Acta BBA Biomembr. 1978, 511, 1-9. [CrossRef]

107. Turkyilmaz, S.; Chen, W.-H.; Mitomo, H.; Regen, S.L. Loosening and Reorganization of Fluid Phospholipid Bilayers by Chloroform. J. Am. Chem. Soc. 2009, 131, 5068-5069. [CrossRef]

108. Nguyen, S.T.; Nguyen, H.T.-L.; Truong, K.D. Comparative cytotoxic effects of methanol, ethanol and DMSO on human cancer cell lines. Biomed. Res. Ther. 2020, 7, 3855-3859. [CrossRef]

109. Murugan, P.; Han, L.; Gan, C.-Y.; Maurer, F.H.; Sudesh, K. A new biological recovery approach for PHA using mealworm, Tenebrio molitor. J. Biotechnol. 2016, 239, 98-105. [CrossRef] [PubMed]

110. Brigham, C.J.; Sinskey, A.J. Applications of polyhydroxyalkanoates in the medical industry. Int. J. Biotechnol. Wellness Ind. 2012, 1, 52-60. [CrossRef]

111. Koller, M.; Niebelschütz, H.; Braunegg, G. Strategies for recovery and purification of poly[(R)-3-hydroxyalkanoates] (PHA) biopolyesters from surrounding biomass. Eng. Life Sci. 2013, 13, 549-562. [CrossRef]

112. Zinn, M.; Witholt, B.; Egli, T. Occurrence, synthesis and medical application of bacterial polyhydroxyalkanoate. Adv. Drug Deliv. Rev. 2001, 53, 5-21. [CrossRef]

113. Cherkin, A. Destruction of bacterial endotoxin pyrogenicity by hydrogen peroxide. Immunochemistry 1975, 12, 625-627. [CrossRef]

114. Lee, S.Y.; Choi, J.-I.; Han, K.; Song, J.Y. Removal of Endotoxin during Purification of Poly(3-Hydroxybutyrate) from Gram-Negative Bacteria. Appl. Environ. Microbiol. 1999, 65, 2762-2764. [CrossRef] [PubMed]

115. Mohapatra, S.; Maity, S.; Dash, H.R.; Das, S.; Pattnaik, S.; Rath, C.C.; Samantaray, D. Bacillus and biopolymer: Prospects and challenges. Biochem. Biophys. Rep. 2017, 12, 206-213. [CrossRef]

116. Valappil, S.P.; Boccaccini, A.R.; Bucke, C.; Roy, I. Polyhydroxyalkanoates in Gram-positive bacteria: Insights from the genera Bacillus and Streptomyces. Antonie Van Leeuwenhoek 2006, 91, 1-17. [CrossRef] [PubMed] 
117. Hazer, B.; Steinbüchel, A. Increased diversification of polyhydroxyalkanoates by modification reactions for industrial and medical applications. Appl. Microbiol. Biotechnol. 2007, 74, 1-12. [CrossRef]

118. Lim, J.; You, M.; Li, J.; Li, Z. Emerging bone tissue engineering via Polyhydroxyalkanoate (PHA)-based scaffolds. Mater. Sci. Eng. C 2017, 79, 917-929. [CrossRef] [PubMed]

119. Liu, Q.; Zhang, H.; Deng, B.; Zhao, X. Poly(3-hydroxybutyrate) and Poly(3-hydroxybutyrate-co-3-hydroxyvalerate): Structure, Property, and Fiber. Int. J. Polym. Sci. 2014, 2014, 374368. [CrossRef]

120. Valappil, S.P.; Misra, S.K.; Boccaccini, A.R.; Roy, I. Biomedical applications of polyhydroxyalkanoates, an overview of animal testing and in vivo responses. Expert Rev. Med. Devices 2006, 3, 853-868. [CrossRef] [PubMed]

121. Larsson, M.; Markbo, O.; Jannasch, P. Melt processability and thermomechanical properties of blends based on polyhydroxyalkanoates and poly(butylene adipate-co-terephthalate). RSC Adv. 2016, 6, 44354-44363. [CrossRef]

122. Ahmed, T.; Marçal, H.; Lawless, M.; Wanandy, N.S.; Chiu, A.; Foster, L.J.R. Polyhydroxybutyrate and its Copolymer with Polyhydroxyvalerate as Biomaterials: Influence on Progression of Stem Cell Cycle. Biomacromolecules 2010, 11, $2707-2715$. [CrossRef]

123. Ferreira, B.M.P.; Duek, E.A.R. Pins composed of poly (L-lactic acid)/poly (3-hydroxybutyrate-co-hydroxyvalerate) PLLA/PHBV blends: Degradation in vitro. J. Appl. Biomater. Biomech. 2005, 3, 50-60. [CrossRef]

124. Wang, Y.; Chen, R.; Cai, J.; Liu, Z.; Zheng, Y.; Wang, H.; Li, Q.; He, N. Biosynthesis and Thermal Properties of PHBV Produced from Levulinic Acid by Ralstonia eutropha. PLoS ONE 2013, 8, e60318. [CrossRef]

125. Wu, C.A.; Pettit, A.R.; Toulson, S.; Grøndahl, L.; Mackie, E.J.; Cassady, A.I. Responsesin vivoto purified poly (3-hydroxybutyrateco-3-hydroxyvalerate) implanted in a murine tibial defect model. J. Biomed. Mater. Res. Part A 2008, 91A, 845-854. [CrossRef]

126. Yagmurlu, M.F.; Korkusuz, F.; Gürsel, I.; Korkusuz, P.; Örs, Ü.; Hasirci, V. Sulbactam-cefoperazone polyhydroxybutyrateco-hydroxyvalerate (PHBV) local antibiotic delivery system: In vivo effectiveness and biocompatibility in the treatment of implant-related experimental osteomyelitis. J. Biomed. Mater. Res. 1999, 46, 494-503. [CrossRef]

127. Ali, I.; Jamil, N. Polyhydroxyalkanoates: Current applications in the medical field. Front. Biol. 2016, 11, 19-27. [CrossRef]

128. Pachekoski, W.M.; Agnelli, J.A.M.; Belem, L.P. Thermal, mechanical and morphological properties of poly (hydroxybutyrate) and polypropylene blends after processing. Mater. Res. 2009, 12, 159-164. [CrossRef]

129. Wu, L.P.; Wang, D.; Parhamifar, L.; Hall, A.; Chen, G.Q.; Moghimi, S.M. Poly(3-hydroxybutyrate-co-R-3-hydroxyhexanoate) nanoparticles with polyethylenimine coat as simple, safe, and versatile vehicles for cell targeting: Population characteristics, cell uptake, and intracellular trafficking. Adv. Healthc. Mater. 2014, 3, 817-824. [CrossRef]

130. Moore, J.E.; Soares, J.S.; Rajagopal, K.R. Biodegradable stents: Biomechanical modeling challenges and opportunities. Cardiovas. Eng. Technol. 2010, 1, 52-65. [CrossRef]

131. Li, Z.; Loh, X.J. Water soluble polyhydroxyalkanoates: Future materials for therapeutic applications. Chemi Soc. Rev. 2015, 44, 2865-2879. [CrossRef] [PubMed]

132. Chanprateep, S. Current trends in biodegradable polyhydroxyalkanoates. J. Biosci. Bioeng. 2010, 110, 621-632. [CrossRef] [PubMed]

133. Chen, G.Q. New challenges and opportunities for industrial biotechnology. Microb. Cell Fact. 2012, 11, 111. [CrossRef] [PubMed]

134. Wong, H.S.J.; Huong, K.H.; Shafie, N.A.H.; Amirul, A.A.A. Genetic incorporation of oil-utilizing ability in Cupriavidus malaysiensis USMAA2-4 for sustainable polyhydroxyalkanoates production from palm olein and 1-pentanol. J. Biotechnol. 2021, 337, 71-79. [CrossRef]

135. Köseoglu, S.S.; Lawhon, J.T.; Lusas, E.W. Membrane processing of crude vegetable oils: Pilot plant scale remoyal of solvent from oil miscellas. J. Am. Oil Chem. Soc. 1990, 67, 315-322. [CrossRef]

136. Li, X.; Du, Y.; Wu, G.; Li, Z.; Li, H.; Sui, H. Solvent extraction for heavy crude oil removal from contaminated soils. Chemosphere 2012, 88, 245-249. [CrossRef]

137. Daly, S.R.; Fathi, A.; Bahramian, B.; Manavitehrani, I.; McClure, D.D.; Valtchev, P.; Schindeler, A.; Dehghani, F.; Kavanagh, J.M. A green process for the purification of biodegradable poly ( $\beta$-hydroxybutyrate). J. Supercrit. Fluids 2018, 135, 84-90. [CrossRef]

138. Policastro, G.; Panico, A.; Fabbricino, M. Improving biological production of poly (3-hydroxybutyrate-co-3-hydroxyvalerate) (PHBV) co-polymer: A critical review. Rev. Environ. Sci. Bio/Technol. 2021, 20, 1-35. [CrossRef]

139. Akaraonye, E.; Keshavarz, T.; Roy, I. Production of polyhydroxyalkanoates: The future green materials of choice. J. Chem. Technol. Biotechnol. 2010, 85, 732-743. [CrossRef]

140. Koller, M. Biodegradable and biocompatible polyhydroxy-alkanoates (PHA): Auspicious microbial macromolecules for pharmaceutical and therapeutic applications. Molecules 2018, 23, 362. [CrossRef]

141. Możejko-Ciesielska, J.; Kiewisz, R. Bacterial polyhydroxyalkanoates: Still fabulous? Microbiol. Res. 2016, 192, 271-282. [CrossRef] [PubMed] 